\title{
産業用超短パルスレーザーの現状と将来展望
}

\author{
浅川雄一 \\ ライテック (株)（テ224-0053 神奈川県横浜市都筑区池辺町4483-1）
}

\section{Current Status and Future View of Industrial Ultra-Short Pulse Lasers}

\author{
Yuichi ASAKAWA \\ Lightec Co., Ltd., 4483-1 Ikebe-cho, Tsuduki, Yokohama, Kanagawa 224-0053
}

(Received July 9, 2013)

\begin{abstract}
Ultra-short pulse laser light sources have been used for scientific research for more than two decade. In spite of this fact, these light sources are not utilized for industrial application. This is because an old type of ones has instability, large foot print and higher price. Recently, various lasing medium, the type of lasing medium, stable oscillator and the way of mode locking enable to make not only ultra-short pulses stable, but a size of light sources compact and a price reasonable. In this paper, current status of industrial ultra-short pulse laser light source is introduced.
\end{abstract}

Key Words: Laser, Laser processing, Industrial ultra-short pulse laser

\section{1.はじめに}

超短パルスレーザー光の特徴は, 短い時間のみ光を発 生させる超短パルス性, 広いスペクトル帯域を有する広 帯域性, そして, 高い電界強度が作り出せる高強度性に あり，その特徴を生かすべく，1980年代後半から超短パ ルス発生，およびその増幅技術は急激に進展し，主に理 科学研究用途に使用され始めた。超短パルス性を活かし た応用例としては, 超高速ダイナミクスの時間分解計測 が代表的な例であり，Zweilが1999年にはノーベル賞を 受賞している1). また，広いスペクトル特性を利用した 応用例としては光周波数コムを用いた精密周波数計測が 挙げられ，本研究においてもHänschが2005年にノーベル 賞を受賞しており2), 超短パルスレーザーは先端理科学 技術には欠かせない道具となっている.

加えて, 高強度性は極短パルス領域となる単一アト秒 パルス発生 ${ }^{3)}$ な゙の理化学応用にも活用されている一方 で，物質に超短パルス光を照射した際に発生する多光子 吸収過程に基づき，熱影響が軽微な加工が実現できる 点, 照射量に応じて加工穴径や深さを精密に調整できる 点, 加えて, 若干の加工レートの違いはあるものの加工 対象の材質を選ばない加工許容性が広い点より, 超短パ ルスレーザーのレーザー加工分野での産業応用が期待さ れてきた4).

しかしながら, 元来, 超短パルスレーザーは理科学用 に開発されてきたため極限技術に近く，産業用途に活用 するにはいくつかの課題があった。第一に安定な出力を 得るためには微妙な光学調整が必要であり, かつ周辺温
度や湿度に対して敏感であることから長期的な出力安定 性が低い点，第二に装置サイズが著しく大きい点，第三 に機械加工と比べてコストが高い反面, 低生産性である ことが挙げられる.

2000年代に入り自動アライメント製造手法などの固体 レーザー製造技術が向上し，また，超短パルスレーザー 光学素子製造技術も分散補償用のミラーが市販され，さ らに，温湿度に対して耐久性をもつ光学素子が開発され たことで一気に信頼性が向上した。加えて，超短パルス 光発生に対して, Ti:sapphire結晶以外にも半導体レー ザーにより直接励起が可能な $\mathrm{Nd}$ 系およびYb系固体レー ザー結晶が活用され，またレーザー媒質の形状として比 較的堅牢性が高いYb系およびEr系ファイバレーザー媒 質も採用され始めた。 さらに，ディスク形状やスラブ形 状のレーザー媒質を利用した増幅器が開発されることに より超短パルスレーザーの高出力化が図られはじめたこ とで, 前述の産業応用に対する課題が解決され始めた。

本稿では，近年著しく発展している産業用超短パルス レーザーの構成や製品に関する現状，および将来展望に ついて解説する。

\section{2. 産業用超短パルスレーザーの構成}

\section{1 概略構成と増幅方法}

一般的に，超短パルスレーザーと称されるレーザー発 振器のパルス幅はフェムト秒領域の場合が多いが，最近 の産業用超短パルスレーザーのレーザー発振器のパルス 幅は数十 ps以下のパルス幅を発生する装置が一般的で 
ある. 加工品質に対するパルス幅の影響は, 加工対象や 目標とする加工品質に依存するところもあるが, パルス 幅20 psを境にして変化が見られる報告がある5)。このた め, 本稿ではフェムト秒領域以長のパルス幅を有する レーザー発振器も産業用超短パルスレーザーに含めるも のとして記載する。

特に超短パルスレーザーをレーザー加工に応用するた めには, そのピーク強度が加工対象の加工しきい值を超 える必要があり, 増幅技術が不可欠となる。 パルス幅が 短くなればなるほど発生や増幅方法は複雑になり, 最終 段で得られるパルス幅により増幅方法はFig. 1に示す通 りにわかれる。その理由として，パルス幅が短くなる と, パルスのピーク強度が $\mathrm{GW} / \mathrm{cm}^{2}$ を超え, そのあたり から結晶や光学素子に損傷が発生する点と物質中の伝搬 によりパルス特性が大きく変化する場合がある点にあ る.

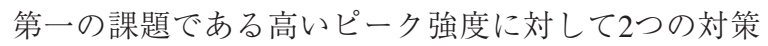
があり，一つが空間的にレーザービームを拡大するこ と, もう一つが時間的にレーザーパルスを引き延ばすこ とによりピーク強度を下げる方法がある. 前者の場合, レーザー装置や利得媒体が大きくなってしまうが, 比較 的一般的な装置構成であるMOPA (Master Oscillator Power Amplifier) 型増幅6)となる。次に，時間的にパルス幅を伸 ばすこととは, 入力パルスに正の分散を与える伸張器で パルス幅を $10^{3} \sim 10^{5}$ 倍に伸張させピーク強度を下げ, こ のパルスを増幅器により所定出力まで増幅させた後, 逆 に負の分散を与える圧縮器でパルスを圧縮させて高い ピーク強度を得る。本手法がチャープパルス増幅法

(Chirped Pulse Amplification: CPA $)^{7-9)}$ である.

第二の課題であるパルス幅の伸張に関して, 一般的に ガラスをはじめとする多くの材料の可視から赤外波長域 にかけて低周波数(長波長側)の光の位相が早く伝搬する 正常分散の性質をもっているためパルス幅が広がる傾向 にある。この現象は群遅延分散と呼ばれ，この現象を補 償する手段の一つに分散補償コーティングが施された誘 電体多層膜ミラーが開発されている。このミラーは多層 膜の各層の膜厚を調整することで長波長側の光が基板内 部で，短波長側の光が膜表面で反射することでガラスが 持つ分散と逆の分散を持たせパルス波形を維持すること が可能になる．特に100 fs以下のパルス幅を伝送する際 は広い帯域を持つため，分散を考慮する必要がある ${ }^{10)}$ 。

また，超短パルスレーザー光は物質中の電子と応答し

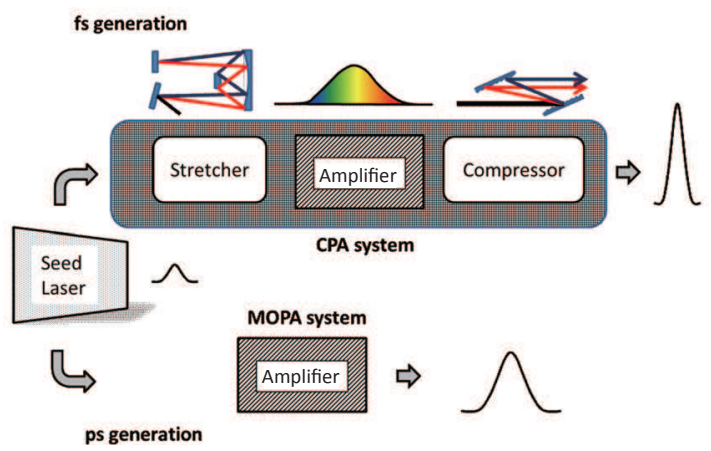

Fig. 1 Schematics of ultra-short pulse amplification.
て高周波分極を誘起し，3次の非線形分極によりレー ザー光のピーク強度に依存して物質中で屈折率変化を引 き起こす。この屈折率変化によりパルス光の位相は非線 形成分を持つようになり，周波数幅が変化し，パルス波 形が延びてしまう。この現象は自己位相変調と呼ばれ， この現象に起因して現時点で高いピーク強度を持つ超短 パルスレーザー光はファイバ伝送できない，加えて，一 般的にレーザー光はガウシアンプロファイルを有しビー ム中心の強度が強いため, 媒質中で空間的にも屈性率変 化を持ってしまい, ビーム中心に向かって屈折率変化が 増大する。この結果, 自己収束が起こり, 極端な例では 照射エネルギーに応じて焦点方向において集光位置が変 わる場合がある。

近年では，これら課題を解決した産業用超短パルス レーザーや光学素子が発売されていており, 煩雑なアラ イメントなしに, キースイッチ操作のみで超短パルスが 得られるまでの完成度に仕上がっている。一般的な産業 用超短パルスレーザーでは, 得られた出力パルスに対し て, 光スイッチング素子を使用して必要な繰返し周波数 に分周して間引きパルスを得る機能のほか, 発振器が有 する発振周波数にならい数発の超短パルストレインが得 られるバースト機能, また, 高調波発生機能を搭載する など，機能面でも充実し始めている，以降，内部を構成 する発振器や増幅器, 機能に関して順次まとめていく。

\section{2 発振器}

最終的にレーザー発振器が出力するパルス幅は, 一部 技術 ${ }^{11}$ を除き, 前述のCPAシステムを経ても発振器で得 られるパルス幅よりも極端に短くなることはない，その ため, 搭載している発振器によりシステム全体のパルス 幅が決定されると言っても過言ではない. パルス幅を短 くすることを念頭に置けば，発振源として，より短いパ ルス幅が得る必要がある一方, 産業用途に耐えうるため には，長期的な安定性，装置大きさや価格，簡便性が重 要であり，そのために様々な選択肢が設けられている.

そもそも超短パルスレーザー光の発生は, Qスイッチ 法 $^{12)}$ や一部例外はあるものの直接変調法 ${ }^{13)}$ のような一般 的なレーザーパルス発生方法では不可能であり，モード 同期法 ${ }^{14)}$ が最も多用されている。モード同期とは，外部 もしくは自発的に発生する変調周期をレーザー共振器内 の光周回時間と合わせることにより，レーザーパルスが 共振器内で特定の発振周波数で同期し, 共振器外に出力 される。よって, 発振器の繰返し周波数は共振器長で決 まり, 以降の増幅を考慮すると発振器では, 背景雑音を 超えるある程度のパルスエネルギーを得る必要があるた め, 共振器長を長く設計する必要が生じる.

このモード同期を実現する選択肢として，レーザー媒 質の形状，モード同期の方法や媒質が挙げられる。前述 のように共振器長を長く設計する必要があるため，比較 的共振器のアライメントは困難である場合が多い。この 課題解決のため, レーザー媒質の形状を考えた際, ファ イバレーザーは複雑なアライメントを必要とせずに, 高 品位なビームが得られ, かつ, ファイバ内で利得が得ら 
れるため，小型かつ簡便な超短パルス発振器として注目 されている. また, 光ファイバによるソリトン動作や非 線形偏波回転を活用し, 安定かつ小型な構成で超短パル スを得る方法なども考案されているが，ファイバを用い るうえでの課題も存在し，ファイバ内部での伝送におい てレーザー光のピーク強度が増すと非線形効果が強くな りパルス幅が延びてしまうため, 得られるパルスエネル ギーやピーク強度に制限があるという欠点もある。その ほかのレーザー媒質の形状としてはロッド型, 最近注目 されているディスク型が挙げられる。特にディスク型は 排熱がロッド型に比べて容易で熱レンズ効果を低減でき る利点はあるものの, 利得媒質長が限られており, 結局 は古典的なロッド型も採用され続けており，三者三様の 利点を有している.

加えて, 最近では半導体レーザー駆動におけるバイア ス電流の急激な変動に伴い誘起される過渡振動応答によ り, 半導体レーザー共振器内で生じる緩和振動を利用し て超短パルスを得る利得スイッチング法が実証されてい る ${ }^{15)}$. 既存のモード同期ではパルス発生タイミングは共 振器長で受動的に決まってしまう反面, この発振方式で は，能動的にパルス発生タイミングを調整できる。発生 パルス幅も $10 \mathrm{ps}$ を切る超短パルス半導体レーザー発振 器も報告されており ${ }^{13)}$, 新たな超短パルスレーザー発振 器の候補として期待されている.

次にモード同期の手法として，これまでのモード同期 の古典的手法である光カー効果を利用したカーレンズ モード同期 ${ }^{16)}$ にとって代わり，比較的安定にモード同期 が可能な半導体可飽和吸収ミラー (Semiconductor Saturable Absorber Mirror: SESAM)をパルス発生誘因とし て使用してモード同期をかける場合が多くなってい る ${ }^{17)}$. 光カー効果とは, 物質中に電場が印加された時に 物質の屈折率が電場強度の二乗に比例して变化する現象 で，この現象に起因するレーザー結晶の自己収束により 加速的に光カー効果を強め, 共振器内に設置されたス リットの透過量を調整してモード同期をかける。簡素な 構成ながらフェムト秒領域でのモード同期が実現できる 反面, Ti:sapphire結晶では発振波長が800 nm付近である ために分散補償プリズムを共振器内に配置する必要があ り，また，吸収波長が可視領域にあることから，装置と しては比較的大型になり, 非常に敏感な共振器調整が必 要となる。一方, SESAMをレーザー媒質とともに共振 器内に設置し用いる場合, SESAMは予め設計された緩 和時間に応じたパルス発生誘因となり，最終的にはカー レンズモード同期によりモード同期がかかる。超短パル ス発生の側面だけを考えればレーザー結晶の自己モード 同期の方が簡素な構成のため望ましいが，SESAMとYb 系媒質やNd系媒質と組み合わせは比較的損傷しきい值 が低い欠点はあるものの，安定なモード同期が得られ， かつ半導体レーザー励起が可能な点からも総合的にみて 非常に簡素かつ堅牢な発振器になりえるため, 最近では 本構成が主流になっている。
Table 1 Comparison of lasing medium for generating ultra-short pulse. ${ }^{\dagger 1}$

\begin{tabular}{cccc}
\hline & Nd:YAG & Ti:sapphire & Yb:YAG \\
\hline $\begin{array}{c}\text { Fluorescence } \\
\text { Wavelength }\end{array}$ & $1064 \mathrm{~nm}$ & $\begin{array}{c}660 \sim \\
1100 \mathrm{~nm}\end{array}$ & $1030 \mathrm{~nm}$ \\
\hline $\begin{array}{c}\text { Fluorescence } \\
\text { Lifetime }\end{array}$ & $\sim 0.23 \mathrm{~ms}$ & $0.0032 \mathrm{~ms}$ & $0.96 \mathrm{~ms}$ \\
\hline $\begin{array}{c}\text { Fluorescence } \\
\text { Spectrum }\end{array}$ & $0.67 \mathrm{~nm}$ & $440 \mathrm{~nm}$ & $9.5 \mathrm{~nm}$ \\
\hline $\begin{array}{c}\text { Transform- } \\
\text { limited pulse }\end{array}$ & $2.5 \mathrm{ps}$ & $2.59 \mathrm{fs}$ & $165 \mathrm{fs}$ \\
\hline $\begin{array}{c}\text { Absorption } \\
\text { Wavelength }\end{array}$ & $807.5 \mathrm{~nm}$ & $488 \mathrm{~nm}$ & $941 \mathrm{~nm}$ \\
\hline $\begin{array}{c}\text { Absorption } \\
\text { Spectrum }\end{array}$ & $1.5 \mathrm{~nm}$ & $200 \mathrm{~nm}$ & $21 \mathrm{~nm}$ \\
\hline $\begin{array}{c}\text { Quantum } \\
\text { Efficiency }\end{array}$ & 0.76 & 0.55 & 0.91 \\
\hline
\end{tabular}

最後に，これまで比較したモード同期法の中でも言及 した結晶の特性をTable 1にて比較する。前述のように, 超短パルスレーザー光発生において最も可能性がある媒 質はTi:sapphire結晶であることは間違いないが，吸収波 長の課題があり， Nd系結晶は古くから完成された結晶 のため高品位かつ安価に手に入れられる利点があるもの の，物性值ではYb系結晶に多くの利点がある。 $\mathrm{Nd}$ 系結 晶と比べると, 蛍光スペクトル幅が長く, フーリエ限界 パルス幅がフェムト秒領域まで短縮可能である。2002年 には更なる広帯域波長可変性も報告されている ${ }^{18)}$ 。 た，量子効率が高いことから高効率なレーザー発振が期 待でき，現在ではYb系の超短パルスレーザーが増えて いる.

\section{3 増幅器}

発振器より得られた超短パルスはFig. 1に示した流れ に従い増幅器により増幅される。CPAおよびMOPA，い ずれの増幅方式の場合でも発振器同様に, 採用する媒質 の特徵は同じである。レーザー媒質の形状において, 増 幅器ではスラブ型が加わる。 スラブ型はディスク型より も冷却効率が高く, 高出力化に向けての有効なレーザー 媒質形状である ${ }^{19)}$ 。ディスク型と比べてモードマッチン グ効率が劣るが，スラブ内をジグザグに導波させるジグ ザグスラブレーザーでは励起に伴う光学歪みを解消する ことができるなどの利点もある ${ }^{20)}$.

それらレーザー媒質を用いて発振器から得られた超短 パルスを増幅していくわけだが，増幅方式は固体レー ザー媒質を用いる際には二つの方式に分かれる。一つが マルチパスアンプ方式，もう一つが再生増幅器方式にな る。基本的にはレーザー媒質に対して光を複数回通過さ せて徐々にパルスエネルギーを増やしていくのだが，マ ルチパスアンプ方式では数枚のミラーを利用してパス回 数を増やす。一方, 再生増幅器では共振器構造を形成す ることでパス数を増やす。前者は発振器出力が安定な場

\footnotetext{
${ }^{\dagger 1}$ http://fuee.u-fukui.ac.jp/ optele/solid_index.htm
} 
合，非常に安定なパルスを出力することができる反面， 不安定なパルスの場合はその不安定性を重畳してしま う. 後者の場合, 共振器内で出力を飽和させるために発 振器で多少不安定な出力でも，原理上，安定なパルスを 得ることができる21)。しかしながらパルスを取り出す夕 イミング制御に対して十分に留意する必要がある.

最近では固体レーザー媒質以外にもファイバを用いた 増幅が注目を集めており，その背景としてファイバ自体 の取り回しの良さと光ファイバ特有の光ファイバラマン 増幅が活用できることにある ${ }^{22)}$ 。これは，光ファイバに 対して強い励起光を入射させるとファイバ内にラマン散 乱が生じ，これに基づく誘導放出が励起光波長より $100 \mathrm{~nm}$ 程度長い波長域にラマン利得波長帯を発生させ る現象であり, 元来この効率が低かったものの, 最近の 通信用光ファイバの開発の進展にもとない, 高非線形か つ低損失な光ファイバが開発され，効率が向上してい る. 前述にもあるが, 光ファイバ内では自己位相変調に よるパルス幅伸張が発生することから超短パルスの発生 には限界があり, 最終的にその発生にはパルス圧縮器を 導入する必要がある。

\section{4 機 能}

モード同期による超短パルスレーザーを発振源とした 場合, 共振器長で決まる基本発振周波数で発振してお り, パルスを間引き増幅する。この発振器から増幅器に 導入する際に複数のパルス列をまとめて増幅器に導入す ることで, Fig. 2に示す通り，超短パルスを短時間のう ちにパルストレインとしてまとめて照射することができ る.この機能はバースト機能と称され, 加工レートの向 上などの報告がなされている。加えて, 増幅器でのゲイ ンを調整して1パルス毎のピーク值を調整して自由に出 カパルスを制御できる技術 ${ }^{2} も$ 開発されており，本技術 による加工技術の発展が期待されている。

また，CPAを搭載したフェムト秒レーザー発振器では 伸張器におけるチャープ量を制御することでパルス幅を 変化させる機能を搭載している光源も製品化されてい る.

超短パルスレーザーでは多光子吸収により, 加工対象 に対して吸収を持たない波長であっても加工することが 可能である. しかしながら, 加工光学系の開口数を同等
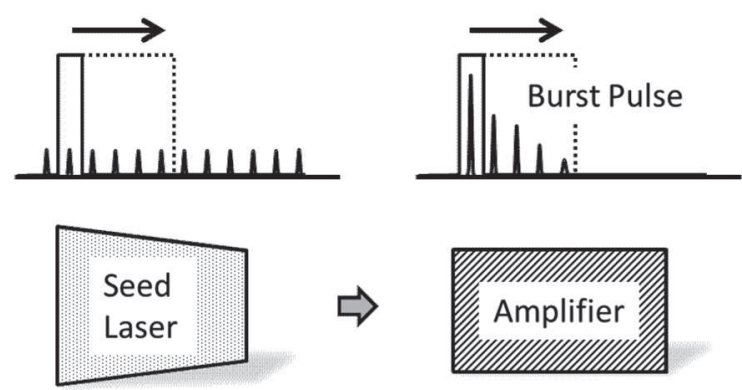

Fig. 2 Schematics of burst pulse generation.
とした場合，波長が短いほど焦点深度が増すことから， 材料に厚みがある場合に波長が短い方が良好な加工レー トを得られる。超短パルスレーザーはパルス幅が短く, ナノ秒レーザー発振器と比べると 1 パルスあたりの $10^{3}$ 〜 10 倍もピーク強度が高いため非線形光学結晶を用いた 波長変換において高い変換効率を得ることができる。そ のため, 非線形光学結晶への集光スポット径を極端に絞 り达む必要がなく，結晶の損傷が起きにくい，第二高調 波あたりでは波長変換を経ても比較的パルスエネルギー が稼げるため, 産業用超短パルスレーザー発振器におい ては比較的多用されている。

\section{3. 産業用超短パルスレーザーの製品}

現在，産業用超短パルスレーザーとして販売されてい る製品をTable 2にまとめる. 各社とも出力水準の違いや 高調波モデルなど多数製品化されているが，最も一般的 なモデルや特徴的なモデルを抜粋して紹介する。これに よると10年前では超短パルスレーザーとして主流であっ たTi:sapphire結晶を用いた光源よりも，より産業用途を 意識したNd系結晶やYb系結晶を用いた光源が増えてい ることが分かる.

\section{4. 産業用超短パルスレーザーの展望}

産業応用への適用を阻害していたレーザー発振器の不 安定は解消され，理化学用途に限られていたような超短 パルスレーザーがターンキーのみですぐに動作する時代 が来ており，その多くの製品が市場に投入されているこ とからも，産業用超短パルスレーザーは今，まさに黎明 期である，既に安定に動作することは当たり前で，各社 とも独自の特徴を持った光源を次々に製品化している. 今後の展望としては, 安定性のほかに産業応用への適用 を阻害している生産性向上につながる高出力化, 廉価 化，および，更なる超短パルス化にあると考える。

高出力化に関しては，パルスエネルギーの向上もしく は高繰返し化になるが，前者に関して，高いパルスエネ ルギーの発生は高いピーク強度を有するためレーザー発 振器内部への負担がかかる点と, 加工に適用する際には 自己位相変調による集光特性の変化や集光点における空 気の電離から生じるエアブレイクダウンによるエネル ギー散逸を考慮して適用しなければならない。また，後 者に関して，発振周波数の高繰返化に対応して，高速か つ高精度に光走査が実現できる光走査デバイスが必要と なる。近年, 位置決め精度が向上したデジタルガルバノ スキャナ，比較的大面積を 1 軸方向に対して高速に光走 査できるレーザー加工用ポリゴンミラーが製品化されて いることや3は偶然の一致ではないと考えられる。

次に廉価化に関して，これだけの製品が市場に投入さ れていることから市場競争原理が働き，非常に高価で

\footnotetext{
${ }^{\dagger 2}$ http://www.time-bandwidth.com/upload/press/flexburst_technology_details.pdf

${ }^{\dagger 3}$ http://nextscantechnolog.com/wp-content/uploads/2013/05/LSE170A_NS_LR.pdf
} 
Table 2 Summary table of Industrial ultra-short pulse lasers.

\begin{tabular}{|c|c|c|c|c|}
\hline Company & Model & Wavelength & Power & Pulsewidth \\
\hline Active Fiber Lasers & Pro-Series & $1030 \mathrm{~nm}$ & $<50 \mathrm{~W}(50 \mathrm{kHz}$ to $1 \mathrm{MHz})$ & $<10 \mathrm{ps}$ \\
\hline \multirow{2}{*}{ Amphos } & Amphos 400 ps & $1030 \mathrm{~nm}$ & $400 \mathrm{~W}(1 \mathrm{MHz}$ to $80 \mathrm{MHz})$ & $<10 \mathrm{ps}$ \\
\hline & Amphos 400 flex & $1030 \mathrm{~nm}$ & $400 \mathrm{~W}(1 \mathrm{MHz}$ to $27 \mathrm{MHz})$ & 500 fs to $5 \mathrm{ps}$ \\
\hline \multirow{2}{*}{ Amplitude System } & Satsuma HP2 & $1030 \mathrm{~nm}$ & $20 \mathrm{~W}$ (0 to $2 \mathrm{MHz})$ & $<400 \mathrm{fs}$ \\
\hline & s-Pulse HP2 & $1030 \mathrm{~nm}$ & $>8 \mathrm{~W}(0$ to $300 \mathrm{kHz})$ & $<500$ fs \\
\hline \multirow{2}{*}{ Attodyne } & APL-X & $1064 \mathrm{~nm}$ & $10 \mathrm{~W}(0$ to $1 \mathrm{MHz})$ & $<10 \mathrm{ps}$ \\
\hline & APLQ & $1064 \mathrm{~nm}$ & $1 \mathrm{~W}(0$ to $1 \mathrm{kHz})$ & $<10 \mathrm{ps}$ \\
\hline Clark MXR & IMPULSE & $1030 \mathrm{~nm}$ & $20 \mathrm{~W}(200 \mathrm{kHz}$ to $25 \mathrm{MHz})$ & $<250$ fs to $>8 \mathrm{ps}$ \\
\hline \multirow{2}{*}{ Coherent } & Talisker HE 1064-10 & $1064 \mathrm{~nm}$ & $10 \mathrm{~W} @ 50 \mathrm{kHz}$ & $<15 \mathrm{ps}$ \\
\hline & Super Rapid 50-1064 & $1064 \mathrm{~nm}$ & $50 \mathrm{~W}(400 \mathrm{kHz}$ to $1 \mathrm{MHz})$ & $<15 \mathrm{ps}$ \\
\hline Corelase & X-LASE 24-6 & $1060 \mathrm{~nm}$ & $24 \mathrm{~W}$ (1to $4 \mathrm{MHz}$ ) & 10 to $30 \mathrm{ps}$ \\
\hline \multirow{2}{*}{ Cyber Laser } & Ifrit & $800 \mathrm{~nm}$ & $1 \mathrm{~W}(0$ to $1 \mathrm{kHz}$ or $2 \mathrm{kHz})$ & $<250$ fs \\
\hline & Ifrit-TD20 & $1030 \mathrm{~nm}$ & $20 \mathrm{~W}$ (50 to $200 \mathrm{kHz})$ & $<3$ ps \\
\hline edgewave & PXxxx-1 & $1064 \mathrm{~nm}$ & $400 \mathrm{~W}(20 \mathrm{MHz})$ & $10 \mathrm{ps}$ \\
\hline EKSPLA & Atlantic 1064 & $1064 \mathrm{~nm}$ & $>16 \mathrm{~W}(1 \mathrm{~Hz}$ to $500 \mathrm{kHz})$ & $<10 \mathrm{ps}$ \\
\hline Fianium & HYLASE-25 & $1064 \mathrm{~nm}$ & $>25 \mathrm{~W}(0.1$ to $1 \mathrm{MHz})$ & $<25 \mathrm{ps}$ \\
\hline Hamamatsu Photonics & MOIL-ps & $1030 \mathrm{~nm}$ & $4 \mathrm{~W}(1$ to $200 \mathrm{kHz})$ & 1.5 to $10 \mathrm{ps}$ \\
\hline IPG photonics & YLPS-20 & $1040 \mathrm{~nm}$ & $20 \mathrm{~W}(10$ to $700 \mathrm{kHz})$ & $<70 \mathrm{ps}$ \\
\hline IMRA & $\mu$ Jewel D-10 K & $1041 \mathrm{~nm}$ & $>10 \mathrm{~W}(1 \mathrm{MHz})$ & $<800$ fs \\
\hline Kataoka & KLY-PSAB 10/25/0.5 A & $1064 \mathrm{~nm}$ & $10 \mathrm{~W}(100 \mathrm{kHz}$ to $800 \mathrm{kHz})$ & $<25 \mathrm{ps}$ \\
\hline Lee Laser & Version 2 & $1064 \mathrm{~nm}$ & $10 \mathrm{~W}(100 \mathrm{kHz}$ to $6 \mathrm{MHz})$ & $15 \mathrm{ps}$ \\
\hline \multirow{2}{*}{ Light conversion } & PHAROS SP & $1030 \mathrm{~nm}$ & $6 \mathrm{~W}(1 \mathrm{~Hz}$ to $200 \mathrm{kHz})$ & 190 fs to $10 \mathrm{ps}$ \\
\hline & PHAROS LP & $1030 \mathrm{~nm}$ & $18 \mathrm{~W}(1 \mathrm{~Hz}$ to $600 \mathrm{kHz})$ & $10 \mathrm{ps}$ \\
\hline onefive & Katana-10 HP & $1064 \mathrm{~nm}$ & $20 \mathrm{~W}(25 \mathrm{kHz}$ to $100 \mathrm{MHz})$ & $<20$ ps to $1 \mathrm{~ns}$ \\
\hline Photon Energy & CEPHEUS 1012 & $1064 \mathrm{~nm}$ & $12 \mathrm{~W}(1 \mathrm{~Hz}$ to $500 \mathrm{kHz})$ & $<15 \mathrm{ps}$ \\
\hline Photonics Industries & RGH-1064-60 & $1064 \mathrm{~nm}$ & $60 \mathrm{~W}(1 \mathrm{MHz})$ & $<15 \mathrm{ps}$ \\
\hline PolarOnyx & Uranus & $1030 \mathrm{~nm}$ etc. & $10 \mathrm{~W}(110 \mathrm{MHz})$ & $<800 \mathrm{fs}$ \\
\hline Quantronix & Integra-HE.E & $800 \mathrm{~nm}$ & $7 \mathrm{~W}(1-2 \mathrm{kHz})$ & 70 to $130 \mathrm{fs}$ \\
\hline Raydiance & $\mathrm{R}-200$ & $1552 \mathrm{~nm}$ & $10 \mathrm{~W}(60 \mathrm{kHz}$ to $1 \mathrm{MHz})$ & $800 \mathrm{fs}$ \\
\hline \multirow{2}{*}{ Spectra Physics } & Spirit $1040-8$ & $1040 \mathrm{~nm}$ & $8 \mathrm{~W}(1 \mathrm{~Hz}$ to $1 \mathrm{MHz})$ & $<400$ fs \\
\hline & Spirit ps $1040-10$ & $1040 \mathrm{~nm}$ & $>10 \mathrm{~W}(1 \mathrm{~Hz}$ to $1 \mathrm{MHz})$ & $13 \mathrm{ps}$ \\
\hline Spectronix & LYF-P0500 & $1064 \mathrm{~nm}$ & $10 \mathrm{~W}(200 \mathrm{kHz}$ to $1 \mathrm{MHz})$ & $11 \mathrm{ps}$ \\
\hline Time-bandwidth Products & PicoBlade & $1064 \mathrm{~nm}$ & $50 \mathrm{~W}(0$ to $8.2 \mathrm{MHz})$ & $10 \mathrm{ps}$ \\
\hline \multirow{2}{*}{ Trumpf } & TruMicro 5080 & $1030 \mathrm{~nm}$ & $150 \mathrm{~W}(800 \mathrm{kHz})$ & $<10 \mathrm{ps}$ \\
\hline & TruMicro 5050 Femto & $1030 \mathrm{~nm}$ & $40 \mathrm{~W}(200$ to $800 \mathrm{kHz})$ & $800 \mathrm{fs}$ \\
\hline
\end{tabular}

あった超短パルスレーザー発振器の值段は下落傾向にあ る.さらにもう一つの背景として, これまで比較的数量 が限られていた超短パルスレーザー用のレーザー部品の 製品安定性が高まり，また，数量が増えることで，部品 レベルで廉価化が進んだことが推測される，今後更なる 産業応用への投入が進むことにより，この傾向は加速し ていくものと考えられる.

最後に，近年の新しい材料やデバイス製造にまつわる 高い要求加工目標はとどまるところを知らない. それに 応えるべく, 加工工法の一つとして, 超短パルスレー ザー光による物質加工が冷却水などの媒体を使用せず
に，非接触，非熱的，かつ精密に物質の除去を可能に し，現在主流の機械加工で実現しえなかった加工を具現 化させる可能性は大いにある。その実現のため，究極を 求めれば更なる短パルス化によるピーク強度の向上，そ れはまさに光で分子間結合を切断する機械加工を超越し た次世代の加工技術への進展に広がる。しかしながらそ の実現に対し，前述のとおり超短パルスレーザー光は広 帯域性を有している点や様々な非線形性を有しているこ とから，極端に扱いが難しくなる１0年程度前は理科学 用に限られていた超短パルスレーザー発振器が, 現在, これほどに産業応用に開発されていることを鑑みれば, 
光学素子に代表される周辺技術の進展も歩を合わせ,さ らなる超短パルスによる新しい加工方法も実現される日 が訪れることが期待される.

$$
\text { 5. まとめ }
$$

本稿において産業用超短パルスレーザーの構成や製品 に関する現状，および将来展望について解説を行った。

現時点でも新しい製品が次々に投入されている状況か らも今後ますますの発展が期待され, 本稿を通じて超短 パルスレーザーへの理解が深まり，その産業応用への一 助になれば幸いである。

\section{謝 辞}

本稿執筆にあたり, 超短パルスレーザー発振器販売元 に製品仕様等の最新資料の提供を受けた。この場を借り てお礼申し上げたい。また，筆者調査不足により未揭載 の情報もあることも予想され, 関係者の方々にはご容赦 願いたい.

\section{参考文献}

1) T. S. Rose, M. J. Rosker, and A. H. Zewail: J. Chem. Phys. 91 (1989) 7515.

2) Th. Udem, R. Holzwarth, and T. W. Hänsch: Nature 416 (2002) 233.
3) M. Hentschel, R. Kienberger, Ch. Spielmann, G. A. Reider, N. Milosevic, T. Brabec, P. Corkum, U. Heinzmann, M. Drescher, and F. Krausz: Nature 414 (2001) 509.

4) 小原實, 神成 文彦, 佐藤 俊一：レーザ応用光学 (共立出 版, 1998) p.252.

5) 小原 實：精密工学会誌 72 (2006) 943.

6) W. Koechner, R. Burnham, J. Kasinski, P. Bournes, D. DiBiase, K. Le, L. Marshall, and A. Hays: Proc. Int'l Conf. Optical Space Com. (Munich, 10-14 June 1991), ed. J. Franz. Proc. SPIE 1522 (1991) 169.

7) E. Treacy: IEEE J. QE-5 (1969) 454

8) O. E. Martinez: IEEE J. QE-23 (1987) 59.

9) D. Strickland and G. Mourou: Opt. Commun. 56 (1985) 219.

10）長谷川 智士：光学 41 (2012) 385.

11) Y. Matsui, M. D. Pelusi, and A. Suzuki: IEEE Photon Tech Lett. 11 (1999) 1217.

12) W. G. Wager and B. A. Lengyel: J. Appl. Phys. 34 (1963) 2040.

13) S. Chen, A. Sato, T. Ito, M. Yoshita, H. Akiyama, and H. Yokoyama: Opt. Express 20 (2012) 24843.

14) E. P. Ippen, C. V. Shank, and A. Dienes: Appl. Phys. Lett. 21 (1972) 348.

15) P. L. Liu, C. Lin, I. P. Kaminow, and J. J. Hsieh: IEEE J. QE-17 (1981) 671.

16) D. E. Spence, P. N. Kean, and W. Sibbett: Opt. Lett. 16 (1991) 42.

17) U. Keller, W. H. Knox, and H. Roskos: Opt. Lett. 15 (1990) 1377.

18) J. Saikawa, S. Kurimura, I. Shoji, and T. Taira: Opt. Mat. 19 (2002) 169.

19) W. Koechner: Solid-state Laser Engineering (Optical sciences, Springer) p.447.

20）川戸栄，末田敬一，小林 喬郎：レーザー研究 33 (2005) 1.

21) W. Koechner: Solid-state Laser Engineering (Optical sciences, Springer) p.563.

22) F. Priolo, G. Franzo, S. Coffa, and A. Carnera: Phys. Rev. B 57 (1998) 444. 